5. Россия впервые вошла в топ-30 рейтинга стран «мягкой силы». URL: http://ria.ru/world/ 20160614/1446947119.html

6. Самые влиятельные женщины мира-2016: рейтинг Forbes. URL: http://www.forbes.ru/ rating-photogallery/322067-samye-vliyatelnye-zhenshchiny-mira-2016-reiting-forbes/photo/1

7. Brandt $W$. Bedeutung und Aufgaben der Auswartigen Kulturpolitik // Bulletin des Presseund Informationsamtes der Bundesregierung. 1967. № 7.

8. Auswдrtige Kulturpolitik 2007 / 2008: Bericht der Bundesregierung. Berlin, 2008.

\section{E.V. Gulina}

Modeling of International Relations in the Central Asian Region on the Principal of Involvement

Issues on homeostatic theory application to international relations are considered for regional systems security and stability model creation. External actors' involvement into the system is analyzed by the example of RussianChinese interaction in Central Asia.

Key words and word-combinations: homeostatic theory, involvement, Central Asia, Russia and China.

Рассматриваются вопросы применения наработок гомеостатики к международным отношениям для построения модели обеспечения безопасности и стабильного развития региональных систем. Анализируется сопричастность внешних акторов системы на примере взаимодействия России и Китая в Центральной Азии.

Ключевые слова и словосочетания: гомеостатика, сопричастность, Центрально-Азиатский регион, Россия и Китай.
DOI 10.22394/1682-2358-2017-1-32-38

УАК 327

ББК 66.4(0)

\section{E.В. Гулина}

\section{МОАЕАИРОВАНИЕ МЕ\КАУНАРОАНЫХ ОТНОШЕНИЙ В ЦЕНТРААЬНО-АЗИАТСКОМ РЕГИОНЕ СОГААСНО ПРИНЦИПУ
СОПРИЧАСТНОСТИ}

$\bigodot_{1}$ пособность политической системы находиться в устойчивом состоянии, адаптироваться к изменяющимся условиям детерминирована ее стремлением к самосохранению и развитию за счет сбалансированности организации и самоорганизации, управмения и самоуправления, нелинейности и цикличности процессов и Ар. [1, с. 579]. При этом поА устойчивостью понимается способность системы преодолевать внешние Аеструктивные воздействия, то есть противостоять внешним угрозам [2, с. 18].

Продуктивное содержание понятия устойчивости политической системы предиагает гомеостатическая теория, в последние годы применяемая не только в теории

32 Bulletin of the Volga Region Institute of Administration • 2017. Vol. 17. № 1 
политических систем [3, с. 482], но и в методологии межАународных отношений [4, с. 43]. Таким образом, применительно к международным отношениям гомеостазис - это сохранение равновесного состояния межАународной политической системы, обеспечиваемое динамическим сбалансированным противодействием и адаптацией образующих ее элементов (субъектов межАународных отношений) к изменениям внутренней и внешней среАы.

Гомеостазис сложных систем, к которым принадлежат и международные помитические системы, устанавливается посредством динамических гомеостатов. Противоречивые свойства таких систем определяют их развитие в конкретных геополитических условиях. Это обусловило применение нами к исследованию региональной системы межжународных отношений в Центральной Азии (далее - ЦА) теории адаптивных систем в сочетании с принципами эмпирической парадигмы. Эмпирический подход позволяет определить характер взаимодействий акторов в рамках географических регионов и сложившихся в них системных связей, общерегионального соотношения сил, связности политической системы со средой и т.п. [5, с. 82-83]. Именно конкретное знание обстановки позволяет применять аАаптивный подход к кажАому проблемному региону.

В соответствии с принципом геополитического регионализма Центрально-Азиатский регион (Аалее - ЦАР) позиџионируется как еАиное геопомитическое пространство межАу основными центрами Евразии, территория с объективно общими дмя занимающих ее государств политическими, экономическими (в том числе транспортными) интересами. Значимость ЦАР как геополитического «хартлэнда» по мере перемешения центра мирового развития в сторону Азиатско-Тихоокеанского региона будет возрастать, поэтому события, происходящие в государствах региона, значимы не только на региональном уровне, способны изменить геополитический баланс сиц на всем евразийском континенте.

Основными эмементами центрацьно-азиатской подсистемы межАународных отношений являются пять респубцик региона - Казахстан, Кыргызстан, Таджикистан, Туркменистан и Узбекистан, - связанных узами разной прочности: от крепких культурно-исторических до ослабленных экономических и отчасти конфронтационных политико-военных. В качестве внерегиональных акторов в Аанную подсистему входят Афганистан, Индия, Иран, Китай, Пакистан, Турџия, Россия, США. Также преАставлены организаџии и объединения, выражающие позиции входящих в них государств: ОАКБ, ШОС, НАТО, $\mathrm{CBM} \Lambda \mathrm{A}$, исламские организации. На стабильность системы влияют внутренние (водная проблема, территориальные разногласия, сепаратистские настроения и Ар.) и внешние (ситуаџия в Афганистане, террористические угрозы, процессы исламизации) факторы. Кроме того, среди самих стран ЦА наблюдается конкуренция за региональное мидерство, сильны разногласия в вопросах использования гидроэнергетических ресурсов, реализаџии региональной интеграции, территориального размежевания, решения межнационацьных конфииктов и т.А., что сильно вцияет на развитие региона.

Алительность дестабилизирующих проџессов, вмияющих на неустойчивость региональной системы ЦАР, говорит о том, что она не обцадает необходимым 
и достаточным адаптационным потенциалом - иными словами, внутренним ресурсом дмя противодействия внешним и внутренним угрозам. Аанную ситуацию отражает и рейтинг по индексу внешних и внутренних угроз, разработанный в рамках проекта «Политический атлас современности» (проект, начатый в 2005 г. МГИМО (У) МИА России совместно с Институтом общественного проектирования и журналом «Эксперт» Аця осуществления комплексного сравнительного анализа политических систем 192 стран мира). Так, Таджикистан и Киргизия занимают в нем 12 и 19 места, соответственно $[6$, c. $164-166]$.

Еще в 2007 г. Н. Назарбаев отметил: «Мы приближаемся к тому, чтобы все международные акторы были заинтересованы в стабильном развитии Центральной Азии, чтобы она стала регионом не соперничества, а нормальной экономической конкуренции в интересах, прежде всего народов, живущих в ... регионе» [7]. Такая ситуация делает потенциально возможным подключение некой внешней силы к процессам развития региона с целью достижения необходимых договоренностей и обеспечения их реализации Амя устойчивости системы. Тем самым будет создан тот адаптационный потенџиал, который на Аанный момент не функционирует.

Управление системой возможно через наращивание гомеостатического потенџиала, поскольку субъект-объектное взаимодействие в рамках гомеостатической теории предполагает возможность варьирования Аоли причастности гомеостатов к жизнедеятельности системы и их функционального Аополнения Аруг Аруга, за счет чего система приобретает способность аАаптироваться к среде и Аостигает устойчивости - гомеостазиса.

ВвиАу текущей невозможности обеспечения безопасности региона ЦАР силами образующих его государств, а также ввиду географического соседства, фактического присутствия и активной вовлеченности в дела региона России и Китая целесообразно рассмотреть возможность создания гомеостатической системы с их участием, что стало бы примером многокритериальной равновесной модели сопричастности акторов к обеспечению региональной безопасности.

ЦАР объективно входит в сферу национальных интересов как России, так и Китая. ОАнако их положение и роль в Центральной Азии имеют опреАеленную специфику. Россия обладает существенным военным ресурсом в ЦА военными базами и объектами в Казахстане, Кыргызстане и Таджикистане, что играет не последнюю роль в стабилизации ситуации в странах региона. Кроме того, традиционно весома пока и роль русского языка, науки и культуры в ЦА, и это обеспечивает присутствие здесь российской «мягкой симы».

У России и Китая есть конкурирующие интересы в экономике ЦАР. В товарообороте с регионом Китай значительно опережает Россию: в 2015 г. показатели стран соотносились как 1 к 0,6 (32,6 мирА Аом.. и 20,8 млрА Аом.., соответственно). Ослабление позиџий России в экономике стран ЦАР обусмовлено сокращением торговых связей, ухудшением качества экспортируемых промышленных товаров и ростом Аоли сырья в торговме. Тем не менее Россия пока сохраняет за собой такие рычаги влияния, как привлечение трудовых

34 Bulletin of the Volga Region Institute of Administration • 2017. Vol. 17. № 1 
мигрантов и, следовательно, денежкные переводы, иьготные поставки военной техники, возможность сбыта продукции стран Центральной Азии в России.

Торгово-экономическая политика КНР в ЦАР наводит на мысль о возрождении традиционных торговых маршрутов. Так, в рамках периферийной Аипломатии появияась концепция «Экономического пояса Шелкового пути», преАполагающая развитие транспортного сообщения в ЦАР и формирование инфраструктурной сети Аля доступа Китая на рынки Южной Азии, Ближнего и Среднего Востока. Таким образом, регион постепенно становится дмя Китая сырьевым и транзитным пространством.

Интересы России и Китая не пересекаются в вопросах трудовой миграџии из стран ЦАР (около 5 млн чел. в Россию против 50 тыс. чел. в Китай), в вопросах военных поставок (Аоминирование России) и развития транспортной инфраструктуры (доминирование Китая). Относительно в равной степени страны преАставлены в гидроэнергетике, нефте- и газопеработке, однако роль Китая в нефтегазовой сфере значительно усиливается [8].

Китай является крупнейшим инвестором в ЦАР, что, с оАной стороны, подАерживает соџиацьно-экономическую стабицьность в регионе, но с Аругой - ставит государства Центральной Азии в зависимость от него и, более того, ведет к росту напряженности и страха в отношениях межАу странами ЦАР и Китаем.

Таким образом, Россия и Китай имеют относительно сопоставимые позиџии в ЦА с преобладанием в тех или иных областях. Это обусловливает необходимость их сотрудничества в обеспечении развития региона. Аанный вывод, в частности, подтверждается результатами опроса, проведенного нами в 2016 г. при помощи online-инструментов среди экспертов России, Китая и стран Центральной Азии (более 150 человек). ОАин из вопросов предполагал ранжирование внерегионацьных акторов по степени их влияния в регионе. Россия и Китай получици 8,1 и 8,5 бамла, соответственно; следом шии Индия и США, получившие по 5,6 бамма.

В этих условиях Аолжен измениться характер межАународных отношений в связи с развитием политики, компенсирующей недостаток адаптивности региональной политической системы. Ресурсной базой может служить стратегия реализации в ЦАР интересов Авух внерегиональных акторов - России и Китая. Аля выявления таких возможностей построим модель сложного Аинамического гомеостата.

В предлагаемом гомеостате Россия и Китай - противоположности-антагонисты ввиду несовпадения их целей в Џентральной Азии. Интересы Китая выражаются в следующем: борьба с сепаратизмом и терроризмом, Аоступ к ресурсам региона, использование его экономического и транзитного потенциала, поддержкание геополитического баланса сим и региональной стабильности [9, с. 85]. По обозначенным вопросам интересы в регионе России и Китая близки, но Россия стремится сохранить свое традиционное влияние в Џентральной Азии, чему препятствует экономическое доминирование КНР. Если Китай делает ставку на экономику, тем самым закрепляя свое присутствие в ЦАР на практике, то Россия стремится действовать иначе, строя планы по 
образованию политического объединения (Евразийского союза), поддерживая военно-политическое сотрудничество (ОАКБ) и опираясь на еАинство ценностей России и государств региона.

Антагонисты, будучи объединены в единую систему, образуют динамический (балансный) гомеостат $[10$, с. 71$]$, который обычно рассматривается в рамках аналитического моделирования и предполагает запись поведения системы в виде функциональных соотношений или могических условий. Оперируя параметрами антагонистов, исследователь может их «склеивать» или «расщеплять, что будет явмяться процессом управления. Естественное «скмеивание» также возможно - это отражает моменты самоорганизации системы и использования ее адаптационного потенциала. ЗАесь реализуется основное правимо гомеостатики - принџип «Аополнительности» оАного антагониста Аругим, в результате чего и образуется динамическая гомеостатическая система.

Как известно, антагонисты находятся в конкурентных отношениях, а их взаимодействие выстраивается относительно определенной нормы. Поскольку целью создания гомеостатической связки «Россия - Китай» явмяется обеспечение безопасности и стабильного развития ЦАР, то такая норма домжна вырабатываться с учетом условий и ситуации в самом регионе с определением «причастности» к ней антагонистов, то есть той роли и тех ресурсов, которые от них требуются. Пара антагонистов «Россия - Китай» можкет анализироваться по следующим направлениям относительно развития системы ЦАР:

- обеспечение военной безопасности: по показателям численности вооруженных сил в ЦАР, количества современного вооружения, количества провоАимых учений в гоА, обменов специалистами со странами ЦАР - с учетом общественного мнения по вопросам военного сотрудничества и размешения военных в странах ЦА;

- обеспечение экономической безопасности: по показателям финансовой подАержки бизнеса при выходе на рынки стран ЦАР, использования возможностей зоны свободной торговли и повышения скорости торговых операций, прямых инвестиций в страны ЦАР, Аостижения безопасности маршрутов с учетом предпринимаемых мер по попумяризаџии сотрудничества, обмену технологиями и специалистами;

- обеспечение миграционной безопасности: по показателям участия в контроле внутренних миграционных потоков, темпов прироста эмиграџии в Россию и Китай, фактического прироста населения в регионе за счет мигрантов из соседних государств с учетом роли в создании условий дмя поддержания постоянного состава насемения в регионе;

- обеспечение технологической безопасности: по показателям участия в технологическом перевооружении и инвестировании в регион, Аокализаџии технологий и создании новых организационных структур научно-технической сферы, участия в исследовательских проектах в регионе, результатов усилий по предотвращению научно-технической разведки, а также экологических и техногенных катастроф;

- обеспечение образовательной безопасности: по показателям финансовой подлержки совместных разработок и студенческого обмена (в том числе по 
языковым программам), упрощения миграционных процедур Аля определенных специальностей, проведения кумьтурных мероприятий.

Таким образом, механизм сопричастности обнаруживается в гармонизаџии усилий России и Китая по отдельным функциям дия формирования общего ответа системы на внешние сигналы и поддержания тем самым ее устойчивости. ОАнако необходим приемлемый баланс сотрудничества через некие пределы присутствия в регионе антагонистов во избежкание прямого столкновения их интересов, с одной стороны, и постепенного превалирования одного из них (что не отвечает интересам государств региона) - с Аругой. НеобхоАимо «распределение обязанностей» через оценку имеющихся ресурсов Аля выявцения оптимацьно возможного участия в регионацьных проџессах.

Еще Пцатон, говоря о соотношении общего и частного, писац о разцичных уровнях совершенства степени сопричастности. Уровень сопричастности определяется Аобровольной «вкцюченностью» субъекта в систему и проџесс в интересах системы: субъект находится как бы между системой, рассматриваемым предметом и своей самостью, своими интересами, поскольку нарушение

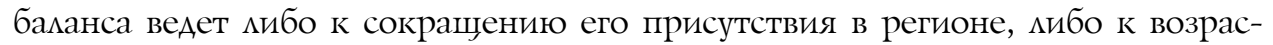
танию его роли и Аоминированию. В рамках рассматриваемой гомеостатической многокритериацьной модели можно вывести слеАующие принципы сопричастности дмя системы межАународных отношений:

1) «сопричастными» к системе могут выступать мюбые внешние акторы, связанные с элементами системы через принцип обратной связи;

2) сопричастность возможкна только в отношении протекающих в системе процессов и вопросов развития самой системы;

3) сопричастность определяется политической волей акторов по отношению к системе и не всегда зависит от воли эцементов системы;

4) оптимахьно Аопустимый уровень сопричастности актора достигается при положительном эффекте от возникающего взаимодействия Аля состояния системы и национацьных интересов актора;

5) модель сопричастности предполагает взаимовыгодное и взаимообусмовленное взаимодействие акторов в регионе в виде их равновесной «специализации» на отдемьных функциях и / или процессах согласно принџипу Аополнительности Аля достижения общих целей, выраженных в установлении необходимой нормы по кажАому отАеАьному Направцению устойчивого состояния и безопасности системы.

Итак, центральным компонентом гомеостатических объектов, в том числе систем межАународных отношений, явцяется встроенное в них противоречие, которое выражено в неспособности системы обеспечить собственное устойчивое состояние и в потенциальной трансформаџии существующей конкуренции ведущих акторов в регионе и стратегических партнеров - России и Китая в открытое столкновение их интересов. Разрешение противоречий происходит через процесс адаптации и гармонизации, что делает необходимым объединение антагонистов. Аинамический балансный гомеостат «Россия - Китай» может выступать регулятором региональной системы ЦАР, обеспечивающим адаптацию системы через их «скмеивание» и дополнение по параметрам, необходимым дия стабилизации системы. 


\section{Библиографический список}

1. Martin R., Sunley P. Complexity Thinking and Evolutionary Economic Geography // Journal of Economic Geography. 2007. Vol. 7, № 5. P. 573-602.

2. Богатуров А.Д., Косолапов Н.А., Хрусталев М.А. Очерки теории и методологии политического анализа международных отношений. М., 2002.

3. Ирхин Ю.В., Зотов В.Д., Зотова Л.В. Политология: учебник. М., 1999.

4. Фельдман Д.М. Международный конфликт и будущее системы международных отношений // Власть. 2010. № 11. С. 39-43.

5. Цыганков П.А. Политическая социология международных отношений. М., 1994.

6. Политический атлас современности: Опыт многомерного статистического анализа политических систем современных государств. М., 2007.

7. Выступление Президента РК Н.А. Назарбаева на VI Евразийском медиа форуме [19.04.2007]. URL: http://kazembassy.ru/ru/posol/oficialnayaastana/vistupleniaprezidentark/ 258-visgoslic 81

8. Перспективы сотрудничества России и Китая в Центральной Азии: рабочая тетрадь / А.А. Казанцев [и др.]. М., 2016. № 28.

9. Чжао Хуашэн. Дипломатия Китая в Центральной Азии. Пекин, 2008.

10. Шевченко A.B. Информационная устойчивость политической системы. М., 2004.

O.N. Kholdorov

\section{The Place and Role of Untraditional} Actors in World Politics

Some criteria of actorness accepted by researchers are argued. The role of the most influential untraditional actors in the modern world politics is analyzed. Attention is focused on their resources of effect.

Key words and word-combinations. untraditional actor, influence, transnational corporation, international non-governmental organization, mass media.

Рассматриваются некоторые из принятых исследователями критериев акторности. Анализируется роль наиболее влиятельных нетрадиционных акторов в современной мировой политике. Акцентируется внимание на ресурсах их влияния.

Ключевые слова и словосочетания: нетрадиционный актор, влиятельность, транснациональная корпорация, международная неправительственная организация, средства массовой информации.
DOI 10.22394/1682-2358-2017-1-38-44

YAK 327

ББК $66.4(0)$

\section{О.Н. Холдоров \\ МЕСТО И РО $\Lambda \mathrm{b}$ \\ НЕТРААИЦИОННЫХ \\ AKTOРОВ \\ В МИРОВОЙ ПОАИТИКЕ}

Б

ольшинство современных исследователей, вкцючая сторонников политического неореализма, согласны с тем, что государства не явцяются единственными акторами, которые могут серьезно влиять на мировую политику и межАународные отношения. Вместе с тем просто признавать их намичие недостаточно, следует акцентировать внимание на их поведении и результатах дейс- 